\title{
Growth and initial development of 'Smooth Cayenne' and 'Pérola' pineapple cultivars, after post-planting herbicides' application
}

André Felipe Moreira Silva, Gustavo Soares da Silva, Ana Carolina Viviani Pagenotto, Ana Ligia Giraldeli, Júlia Pereira de Moraes, Beatriz Sizilio dos Santos, Giovani Apolari Ghirardello, Ricardo Victoria Filho

Universidade de São Paulo, Escola Superior de Agricultura "Luiz de Queiroz" - Esalq, Piracicaba, SP. E-mail: afmoreirasilva@hotmail.com

\begin{abstract}
There is a lack of information regarding the use of herbicides in pineapple crop, so the aim was to evaluate the growth and initial development of 'Smooth Cayenne' and 'Pérola' pineapple seedlings under application of diuron, sulfentrazone and ametryn, isolated and associated, in post-planting. The experiments were conducted in a greenhouse and the treatments consisted on application of herbicides after planting. Crop injury, leaf length, dry leaf mass and total aerial part were evaluated. The initial growth and development of the 'Smooth Cayenne' pineapple seedlings were not negatively influenced by the application of diuron. The initial growth and development of pineapple seedlings 'Pérola' was not negatively influenced by the application of diuron and ametryn, isolated or associated.
\end{abstract}

Keywords: Ananas comosus; diuron; sulfentrazone; ametryn; chemical management.

\section{Crescimento e desenvolvimento inicial de abacaxi, cultivares 'Smooth Cayenne' e 'Pérola', sob aplicação de herbicidas em pós-plantio}

\section{Resumo}

Há déficit de informações a respeito do uso de herbicidas no cultivo de abacaxi, assim objetivou-se avaliar o crescimento e desenvolvimento inicial de mudas de abacaxi 'Smooth Cayenne' e 'Pérola' sob aplicação de diuron, sulfentrazone e ametryn, isolados e em associações, em pós-plantio. Os experimentos foram conduzidos em casa de vegetação e os tratamentos foram compostos pela aplicação em pós-plantio dos herbicidas. Foram avaliados sintomas de injúria, comprimento de folha e massa seca de folha e parte aérea total. O crescimento e desenvolvimento inicial das mudas de abacaxi cultivar 'Smooth Cayenne' não foram influenciados negativamente pela aplicação de diuron. O crescimento e desenvolvimento inicial das mudas de abacaxi cultivar 'Pérola' não foi influenciado negativamente pela aplicação de diuron e ametryn, isolados ou associados entre si.

Palavras-chave: Ananas comosus; diuron; sulfentrazone; ametryn; manejo químico.

\section{Introduction}

The presence of weeds is one of the main factors that may interfere on the development of pineapple (Ananas comosus) crop. Since the pineapple plants exhibit slow growth and shallow root system. Thus, ineffective weed control is a limiting factor in the pineapple crop yield (CATUNDA et al., 2005; CATUNDA et al., 2006; SRIPAORAYA et al., 2006).
The herbicides application in the crop brings several benefits, such as more effective weed control in the planting lines, without damaging the root system, time flexibility on application, labor reduction, among others (MODEL et al., 2006; MATOS et al., 2009; MODEL; FAVRETO, 2010). Despite this, the number of selective herbicides for pineapples and preformulated mixtures registered in Brazil is restricted with only four active ingredients 
(MELETTI et al., 2011; MINISTÉRIO DA AGRICULTURA, BRASIL, 2018; RODRIGUES; ALMEIDA, 2018).

Among the herbicides recommended for use in pineapple, only three can be applied in post-planting in total area, however with restrictions on the stage of development of pineapple plants and the number of applications during a crop cycle (RODRIGUES; ALMEIDA, 2018). It may be noted in this regard the herbicide diuron, which is a photosystem II inhibitor, presenting an efficiency in preemergence and early post to control both monocotyledons and eudicotyledons weeds (OLIVEIRA JÚNIOR, 2011).

Among the cultivars most planted in Brazil, it can be highlighted 'Smooth Cayenne' and 'Pérola'. Thefirst one is also known as 'Hawaii', presents semi-cartilage, leaves without spines (except some found at the apical edge of the leaf edge), ovoid fruit weighing from 1.5 to $2.5 \mathrm{~kg}$ with orange yellow peel at the base when ripe, yellow flesh, rich in sugars (13-19 $\mathrm{oBrix}$ ) and higher acidity than other cultivars. The cultivar 'Pérola', also known as 'Pernambuco' presents medium size and erect growth, leaves with spines at the edges, conical fruit weighing 1.0 to $1.5 \mathrm{~kg}$, with yellow peel when ripe, white, rich pulp in sugars (14-16 Brix) and low acid (CABRAL, 2003).

It is clear the lack of information regarding the use of herbicides in the pineapple crop, especially for application in the postplanting. Thus, the aim of this study was to evaluate the growth and initial development of pineapple (A. comosus) seedlings 'Smooth Cayenne' and 'Pérola', under application of diuron, sulfentrazone and ametryn, isolated and in associations in post-planting.

\section{Materials and Methods \\ Design and experimental conditions}

Two experiments were conducted in a greenhouse in Piracicaba, São Paulo state, Brazil $\left(22^{\circ} 42^{\prime} 30.9^{\prime \prime} \mathrm{S} 47^{\circ} 37^{\prime} 42.9^{\prime \prime} \mathrm{W}\right)$. For the experiment I, it was used the cultivar 'Smooth Cayenne', and for the second, the 'Pérola' cultivar. These two cultivars were chosen because they are the most cultivated in Brazil (MATOS, 2012).

A completely randomized design with four replications was used. The treatments were composed by application of diuron, sulfentrazone and ametryn, isolated and associated, at postplanting and the treatments are showed in Table 1.

Table 1. Treatments applied in post-planting of pineapple plants, Piracicaba, São Paulo, Brazil. 2016/17.

\begin{tabular}{lll}
\hline \multirow{2}{*}{ Treatments $^{1}$} & \multicolumn{2}{c}{ Rates $^{2}$} \\
\cline { 2 - 3 } & $1^{\text {st }}$ application & $2^{\text {nd }}$ application \\
\hline 1. control (without application) & - & - \\
2. diuron & 2000 & - \\
3. diuron & 2000 & 2000 \\
4. sulfentrazone & 700 & - \\
5. sulfentrazone & 700 & 700 \\
6. ametryn & 1500 & - \\
7. ametryn & 1500 & 1500 \\
8. diuron + sulfentrazone & $2000+700$ & - \\
9. diuron + sulfentrazone & $2000+700$ & $2000+700$ \\
10. diuron + ametryn & $2000+1500$ & - \\
11. diuron + ametryn & $2000+1500$ & $2000+1500$ \\
12. diuron + sulfentrazone + ametryn & $2000+700+1500$ & - \\
\hline
\end{tabular}

'Comercial products: Diuron Nortox 500 SC (diuron), Boral 500 SC (sulfentrazone), Gesapax 500 CibaGeigy (ametryn). ${ }^{2}$ Rates in grams of active ingredient per hectare ( $\mathrm{g}$ a.i. ha $^{-1}$ ).

The experimental units consisted of pots with a volume of $8.0 \mathrm{dm}^{3}$, filled with sandy soil, fertilized before planting. The planting was carried out on July 18, 2016, using one seedling per pot. The first application was performed at 25 days after planting (DAP) and the second one at 75 DAP.
The application was made through a $\mathrm{CO}_{2}$ backpack sprayer, consisted of a four-nozzle boom fitted with four XR 110.015 flat-fan nozzles, calibrated to deliver a volume of $200 \mathrm{~L} \mathrm{ha}^{-1}$ at a constant pressure of 2 bar. 


\section{Evaluations and data collection}

Visual assessments of crop injury in pineapple plants were performed at $82,96,110$, 124, 138, 152 and 175 DAP. Percentage notes were assigned to each experimental unit ( 0 for no injury, up to $100 \%$ for plant death), considering in this case the visible symptoms in the plants, according to their development (VELINI et al., 1995).

Furthermore, at 96, 110, 124, 138, 152 and 175 DAP it was evaluated the leaf length. At 96 DAP, the fifth leaf was identified from the center, clockwise, and during the following evaluations this same leaf had its length measured through a graduated ruler expressing the results in centimeters.

At 175 DAP the aerial part was collected and oven-dried for $72 \mathrm{~h}$ at $65 \stackrel{\circ}{\circ}$. Subsequently, the leaf dry mass was identified for the evaluations and the total dry mass of the aerial part of the plants was weighed in analytical scale, with precision of two decimal places, expressed in grams.

\section{Statistical analysis}

The data was analyzed according to Pimentel-Gomes and Garcia (2002) through analysis of variance $(p<0.05)$, and it was applied a Scott and Knott (1974) test for grouping means $(p<0.05)$.

Results

Crop injury

Crop injury on pineapple plants was observed in both cultivars due to herbicide application at post-planting. For the cultivar 'Smooth Cayenne' crop injury was observed especially in the treatments involving the application of sulfentrazone and ametryn (two applications), presenting higher percentages up to 175 DAP. The highest percentage was verified at 124 DAP (33.75\%), for ametryn (two applications), which was higher than that observed for all other treatments (Table 2).

For plants of the 'Pérola' cultivar more severe injury was observed for sulfentrazone, isolated or associated with diuron, always in two applications, presenting higher values than $60 \%$ at 96,110 and 124 DAP. No differences were observed between the other treatments at 152 and 175 DAP (Table 3).

It also highlights that diuron in one or two applications, did not differ from the control treatment (without application) in any of the crop injury evaluations for both cultivars.

Table 2. Crop injury (\%) of pineapple plants, 'Smooth Cayenne' cultivar, under application of herbicides at post-planting. Piracicaba, São Paulo, Brazil. 2016/17.

\begin{tabular}{|c|c|c|c|c|c|c|c|c|c|c|c|c|c|c|}
\hline \multirow{3}{*}{ Treatments ${ }^{1}$} & \multicolumn{14}{|c|}{ Crop injury } \\
\hline & \multicolumn{2}{|l|}{82} & \multicolumn{2}{|l|}{96} & \multicolumn{2}{|l|}{110} & \multicolumn{2}{|l|}{124} & \multicolumn{2}{|l|}{138} & \multicolumn{2}{|l|}{152} & \multicolumn{2}{|l|}{175} \\
\hline & & & & & & & DAP & & & & & & & \\
\hline 1. $\mathrm{co}$ & 0.00 & $\mathrm{a}$ & 0.00 & $\mathrm{a}$ & 0.00 & $a$ & 0.00 & $\mathrm{a}$ & 0.00 & $\mathrm{a}$ & 0.00 & $a$ & 0.00 & $\mathrm{a}$ \\
\hline 2. diu & 1.25 & a & 0.00 & $\mathrm{a}$ & 1.25 & a & 1.25 & $\mathrm{a}$ & 1.25 & $\mathrm{a}$ & 1.25 & a & 1.25 & $\mathrm{a}$ \\
\hline 3. $\mathrm{diu}^{2}$ & 1.25 & $\mathrm{a}$ & 3.75 & $\mathrm{a}$ & 3.75 & a & 1.25 & $\mathrm{a}$ & 0.00 & $\mathrm{a}$ & 0.00 & a & 0.00 & $\mathrm{a}$ \\
\hline 4. sul & 3.75 & a & 3.75 & $\mathrm{a}$ & 15.00 & $b$ & 16.25 & $b$ & 13.75 & $b$ & 13.75 & $b$ & 11.25 & $b$ \\
\hline 5. sul ${ }^{2}$ & 5.00 & $\mathrm{a}$ & 10.00 & $b$ & 17.50 & $b$ & 16.25 & $b$ & 15.00 & $b$ & 10.00 & $b$ & 7.50 & $b$ \\
\hline 6. ame & 0.00 & $\mathrm{a}$ & 1.25 & $\mathrm{a}$ & 3.75 & a & 3.75 & $\mathrm{a}$ & 3.75 & $\mathrm{a}$ & 2.50 & $\mathrm{a}$ & 2.50 & $\mathrm{a}$ \\
\hline 7. $a m e^{2}$ & 8.75 & $\mathrm{~b}$ & 13.75 & $\mathrm{~b}$ & 27.50 & $\mathrm{~b}$ & 33.75 & c & 31.25 & c & 22.50 & $b$ & 17.50 & $\mathrm{~b}$ \\
\hline 8. diu + sul & 3.75 & $\mathrm{a}$ & 3.75 & $\mathrm{a}$ & 8.75 & $a$ & 7.50 & $\mathrm{a}$ & 6.25 & $\mathrm{a}$ & 3.75 & $\mathrm{a}$ & 3.75 & $\mathrm{a}$ \\
\hline 9. $d i u+\left.s u\right|^{2}$ & 8.75 & $b$ & 12.50 & $b$ & 16.25 & $b$ & 18.75 & $b$ & 17.50 & $b$ & 13.75 & $b$ & 10.00 & $b$ \\
\hline 10. diu + ame & 10.00 & $\mathrm{~b}$ & 8.75 & $b$ & 6.25 & a & 5.00 & $\mathrm{a}$ & 6.25 & $\mathrm{a}$ & 6.25 & a & 5.00 & $\mathrm{a}$ \\
\hline 11. diu $+a m e^{2}$ & 2.50 & $a$ & 3.75 & $a$ & 13.75 & $\mathrm{~b}$ & 11.25 & $a$ & 10.00 & $a$ & 7.50 & a & 6.25 & $a$ \\
\hline 12. diu + sul + ame & 3.75 & $\mathrm{a}$ & 8.75 & $b$ & 10.00 & $b$ & 11.25 & $\mathrm{a}$ & 11.25 & $\mathrm{a}$ & 10.00 & $\mathrm{~b}$ & 8.75 & $\mathrm{~b}$ \\
\hline Mean & 4.06 & & 5.83 & & 10.31 & & 10.5 & & 9.69 & & 7.60 & & 6.15 & \\
\hline C.V. (\%) & 45.75 & & 44.45 & & 43.60 & & 44.4 & & 39.30 & & 41.02 & & 38.80 & \\
\hline $\mathrm{F}$ & $2.28^{*}$ & & $3.02^{*}$ & & $2.36^{*}$ & & 3.42 & & $4.48^{*}$ & & $3.06^{*}$ & & $3.24^{*}$ & \\
\hline
\end{tabular}

${ }^{1} \mathrm{co}$ (control), diu (diuron - $2000 \mathrm{~g}$ a.i. ha ${ }^{-1}$ ), sul (sulfentrazone - $700 \mathrm{~g}$ a.i. ha ${ }^{-1}$ ), ame (ametryn $-1500 \mathrm{~g}$ a.i. ha ${ }^{-1}$ ). Single application for even number treatments. ${ }^{2}$ Two applications for these treatments. DAP (days after planting), C.V. (coefficient of variation). *Means followed by the same letter in the column do not differ from one another by Scott and Knott's (1974) test $(p<0.05)$. 
Table 3. Crop injury (\%) of pineapple plants, 'Pérola' cultivar, under application of herbicides at postplanting. Piracicaba, São Paulo, Brazil. 2016/2017.

\begin{tabular}{|c|c|c|c|c|c|c|c|c|c|c|c|c|c|c|}
\hline \multirow{3}{*}{ Treatments $^{1}$} & \multicolumn{14}{|c|}{ Crop injury } \\
\hline & \multicolumn{2}{|l|}{82} & \multicolumn{2}{|l|}{96} & \multicolumn{2}{|l|}{110} & \multicolumn{2}{|l|}{124} & \multicolumn{2}{|l|}{138} & \multicolumn{2}{|l|}{152} & \multicolumn{2}{|l|}{175} \\
\hline & & & & & & & DAP & & & & & & & \\
\hline 1. co & 0.00 & $a$ & 0.00 & $a$ & 0.00 & $a$ & 0.00 & $a$ & 0.00 & $a$ & 0.00 & $a$ & 0.00 & $a$ \\
\hline 2. diu & 0.00 & a & 0.00 & a & 0.00 & a & 0.00 & a & 0.00 & a & 0.00 & a & 0.00 & a \\
\hline 3. $d i u^{2}$ & 0.75 & $a$ & 0.00 & $a$ & 0.75 & a & 0.00 & $\mathrm{a}$ & 0.00 & $a$ & 0.00 & a & 0.00 & $a$ \\
\hline 4. sul & 25.00 & c & 18.75 & b & 10.00 & b & 7.00 & b & 5.00 & b & 0.00 & a & 0.00 & a \\
\hline 5. sul ${ }^{2}$ & 40.00 & $d$ & 62.50 & c & 67.50 & c & 65.00 & $c$ & 52.50 & c & 42.50 & $b$ & 32.50 & $b$ \\
\hline 6. ame & 0.75 & a & 0.00 & a & 0.00 & $a$ & 0.00 & a & 0.00 & $a$ & 0.00 & a & 0.00 & $a$ \\
\hline 7. $a m e^{2}$ & 1.75 & a & 1.25 & a & 0.75 & $a$ & 0.00 & $\mathrm{a}$ & 0.00 & $a$ & 0.00 & a & 0.00 & $a$ \\
\hline 8. diu + sul & 17.50 & b & 10.50 & b & 4.00 & a & 0.00 & a & 0.00 & a & 0.00 & a & 0.00 & a \\
\hline 9. diu + sul ${ }^{2}$ & 48.75 & $d$ & 65.00 & c & 68.75 & c & 68.75 & c & 62.50 & $d$ & 55.00 & c & 46.25 & c \\
\hline 10. diu + ame & 0.50 & a & 0.00 & a & 0.00 & a & 0.00 & a & 0.00 & a & 0.00 & a & 0.00 & a \\
\hline 11. diu $+a m e^{2}$ & 16.25 & $b$ & 17.50 & $b$ & 13.75 & b & 11.25 & $b$ & 11.25 & $b$ & 6.25 & a & 3.75 & a \\
\hline 12. diu + sul + ame & 31.25 & c & 22.50 & $\mathrm{~b}$ & 13.25 & b & 11.25 & $\mathrm{~b}$ & 5.00 & $\mathrm{~b}$ & 5.00 & a & 2.50 & a \\
\hline Mean & 15.21 & & 16.56 & & 14.90 & & 13.60 & & 10.94 & & 9.06 & & 7.08 & \\
\hline C.V. (\%) & 23.90 & & 21.43 & & 26.36 & & 32.28 & & 32.96 & & 29.66 & & 31.20 & \\
\hline $\mathrm{F}$ & 21.54 & & $62.15^{\circ}$ & & $85.55^{\circ}-x$ & & 68.49 & & $72.68^{*}$ & & $60.66^{\prime}$ & & $23.00 *$ & \\
\hline
\end{tabular}

${ }^{1} \mathrm{co}$ (control), diu (diuron - $2000 \mathrm{~g}$ a.i. ha ${ }^{-1}$ ), sul (sulfentrazone - $700 \mathrm{~g}$ a.i. $\mathrm{ha}^{-1}$ ), ame (ametryn $-1500 \mathrm{~g}$ a.i. ha ${ }^{-1}$ ). Single application for even number treatments. ${ }^{2}$ Two applications for these treatments. DAP (days after planting), C.V. (coefficient of variation). *Means followed by the same letter in the column do not differ from one another by Scott and Knott's (1974) test $(p<0.05)$.

\section{Growth and initial development}

The analysis of variance of the data was conclusive for the leaf length variable, with regard to the 'Smooth Cayenne' cultivar pineapple plants (Table 4). There were no differences between treatments at all the evaluation dates.

Table 4. Result of the analysis of variance for leaf length variable $(\mathrm{cm})$ of pineapple plants, 'Smooth Cayenne' cultivar. Piracicaba, São Paulo, Brazil. 2016/17.

\begin{tabular}{lccccccc}
\hline \multirow{2}{*}{ Font } & DF & \multicolumn{7}{c}{ DAP } \\
\cline { 3 - 8 } & & 96 & 110 & 124 & 138 & 152 & 175 \\
\cline { 3 - 8 } & 11 & $1.29^{\text {ns }}$ & $1.83^{\text {ns }}$ & $1.50^{\text {ns }}$ & $1.85^{\text {ns }}$ & $2.10^{\text {ns }}$ & $1.79^{\text {ns }}$ \\
\hline Treatments & Mean & 13.46 & 21.71 & 29.82 & 34.44 & 36.58 & 38.23 \\
\hline & C.V. (\%) & 30.22 & 24.63 & 26.82 & 26.25 & 26.68 & 29.21 \\
\hline
\end{tabular}

DF (degrees of freedom), DAP (days after planting), C.V. (coefficient of variation). ${ }^{\text {ns }}$ non-significant, means of treatments do not differ each other $(p<0.05)$.

For the 'Pérola' cultivar, leaf length differences were verified at 110, 124 and 138 DAPin the treatments involving sulfentrazone, isolated or in tank mixture with diuron. When received two applications, it presented a lower leaf length than that observed for all other treatments. During the other dates no differences were observed between treatments (Table 5). 
Table 5. Leaf length $(\mathrm{cm})$ of pineapple plants, 'Pérola' cultivar, under application of herbicides at postplanting. Piracicaba, São Paulo, Brazil, 2016/17.

\begin{tabular}{|c|c|c|c|c|c|c|c|c|c|}
\hline \multirow{3}{*}{ Treatments $^{1}$} & \multicolumn{9}{|c|}{ Leaf length } \\
\hline & 96 & 110 & & 124 & & 138 & & 152 & 175 \\
\hline & \multicolumn{9}{|c|}{ DAP } \\
\hline 1. co & 24.50 & 38.00 & $a$ & 41.25 & $a$ & 41.75 & $a$ & 42.75 & 42.75 \\
\hline 2. diu & 25.25 & 39.00 & a & 43.75 & $a$ & 45.25 & a & 45.25 & 47.25 \\
\hline 3. $\mathrm{diu}^{2}$ & 25.75 & 36.75 & a & 40.00 & $a$ & 41.00 & a & 42.00 & 42.00 \\
\hline 4. sul & 25.00 & 35.75 & a & 39.00 & $a$ & 39.75 & a & 40.50 & 42.00 \\
\hline 5. sul ${ }^{2}$ & 25.00 & 29.75 & $b$ & 34.00 & $\mathrm{~b}$ & 36.25 & $b$ & 38.00 & 38.50 \\
\hline 6. ame & 26.50 & 36.50 & a & 41.75 & $a$ & 42.75 & a & 44.75 & 47.00 \\
\hline 7. $a m e^{2}$ & 25.50 & 36.00 & a & 41.25 & $a$ & 43.25 & a & 42.50 & 44.00 \\
\hline 8. diu + sul & 23.50 & 36.50 & a & 40.25 & $a$ & 43.25 & $\mathrm{a}$ & 44.00 & 44.75 \\
\hline 9. $d i u+\left.s u\right|^{2}$ & 20.75 & 26.50 & $b$ & 31.75 & $b$ & 33.75 & $b$ & 34.25 & 34.25 \\
\hline 10. diu + ame & 25.50 & 37.25 & a & 41.25 & $a$ & 42.00 & a & 43.00 & 44.00 \\
\hline 11. diu $+a m e^{2}$ & 24.50 & 33.75 & a & 37.00 & $b$ & 38.75 & $b$ & 39.75 & 39.75 \\
\hline 12. diu + sul + ame & 27.00 & 37.50 & a & 39.50 & $a$ & 41.25 & a & 42.00 & 43.25 \\
\hline Mean & 24.90 & 35.27 & & 39.23 & & 40.67 & & 41.56 & 42.46 \\
\hline C.V. (\%) & 9.98 & 8.45 & & 8.69 & & 9.97 & & 10.49 & 11.13 \\
\hline $\mathrm{F}$ & $1.65^{\mathrm{ns}}$ & $5.98 *$ & & $4.04^{*}$ & & $2.43^{*}$ & & $2.01^{\mathrm{ns}}$ & $2.36^{\text {ns }}$ \\
\hline
\end{tabular}

${ }^{1} \mathrm{co}$ (control), diu (diuron - $2000 \mathrm{~g}$ a.i. ha ${ }^{-1}$ ), sul (sulfentrazone $-700 \mathrm{~g}$ a.i. ha ${ }^{-1}$ ), ame (ametryn $-1500 \mathrm{~g}$ a.i. ha ${ }^{-1}$ ). Single application for even number treatments. ${ }^{2}$ Two applications for these treatments. DAP (days after planting), C.V. (coefficient of variation). *Means followed by the same letter in the column do not differ from one another by Scott and Knott's (1974) test $(p<0.05) .{ }^{\text {ns }}$ non-significant, means of treatments do not differ each other $(p<0.05)$.

The diuron, in one or two applications, did not reduce the dry leaf mass of the 'Smooth Cayenne' plants in relation to the control treatment. As well as the treatments ametryn, diuron + sulfentrazone and diuron + ametryn, for single application, other treatments reduced leaf dry mass in comparison to the control treatment. For total dry mass ('Smooth Cayenne' cultivar), all herbicide treatments reduced values, except for diuron in one or two applications (Table 6).
While for the 'Pérola' cultivar, the sulfentrazone, diuron + sulfentrazone and diuron + ametryn treatments, in two applications, reduced leaf dry mass of pineapple plants, among the other treatments no differences were observed. Sulfentrazone isolated or associated, for one or two applications, reduced the total dry mass of the aerial part. In the treatments without sulfentrazone, no reductions were verified (Table 6). 
Table 6. Dry mass (g) of leaf (DML) and dry mass (g) of shoot (DMS) of pineapple plants, 'Smooth Cayenne' and 'Pérola' cultivars, under application of herbicides at post-planting. Piracicaba, São Paulo, Brazil, 2016/17.

\begin{tabular}{|c|c|c|c|c|c|c|c|c|}
\hline \multirow{2}{*}{ Treatments $^{1}$} & \multicolumn{4}{|c|}{ 'Smooth Cayenne' } & \multicolumn{4}{|c|}{ 'Pérola' } \\
\hline & \multicolumn{2}{|l|}{ DML } & \multicolumn{2}{|l|}{ DMS } & \multicolumn{2}{|l|}{$\mathrm{DML}$} & \multicolumn{2}{|l|}{ DMS } \\
\hline 1. co & 3.23 & $a$ & 306.96 & $\mathrm{a}$ & 2.55 & $\mathrm{a}$ & 91.39 & $\mathrm{a}$ \\
\hline 2. diu & 3.61 & a & 279.81 & $\mathrm{a}$ & 2.65 & $\mathrm{a}$ & 104.84 & $\mathrm{a}$ \\
\hline 3. diu $^{2}$ & 2.93 & a & 268.68 & $\mathrm{a}$ & 1.99 & $\mathrm{a}$ & 100.78 & $\mathrm{a}$ \\
\hline 4. sul & 1.73 & $b$ & 203.32 & $b$ & 1.79 & $\mathrm{a}$ & 66.07 & $b$ \\
\hline 5. sul ${ }^{2}$ & 1.85 & $b$ & 194.36 & $b$ & 1.64 & $b$ & 28.09 & c \\
\hline 6. ame & 2.75 & a & 196.68 & $b$ & 2.38 & $\mathrm{a}$ & 76.67 & $\mathrm{a}$ \\
\hline 7. $a m e^{2}$ & 2.07 & $b$ & 121.51 & c & 2.41 & $\mathrm{a}$ & 83.16 & $\mathrm{a}$ \\
\hline 8. diu + sul & 2.57 & a & 189.66 & $b$ & 2.14 & $\mathrm{a}$ & 64.49 & $b$ \\
\hline 9. $d i u+\left.s u\right|^{2}$ & 1.61 & $b$ & 187.82 & $b$ & 0.84 & $b$ & 30.41 & c \\
\hline 10. diu + ame & 2.52 & a & 216.90 & $b$ & 2.07 & $\mathrm{a}$ & 92.02 & $\mathrm{a}$ \\
\hline 11. $d i u+a m e^{2}$ & 1.36 & $b$ & 202.97 & $b$ & 1.64 & $b$ & 76.05 & $\mathrm{a}$ \\
\hline 12. diu + sul + ame & 1.85 & $\mathrm{~b}$ & 196.60 & $\mathrm{~b}$ & 2.00 & $\mathrm{a}$ & 59.25 & $\mathrm{~b}$ \\
\hline Mean & 2.33 & & 213.77 & & 1.96 & & 72.77 & \\
\hline C.V. (\%) & 13.10 & & 15.58 & & 26.17 & & 20.36 & \\
\hline $\mathrm{F}$ & $3.18^{*}$ & & $8.86^{*}$ & & $4.63^{*}$ & & $8.39 *$ & \\
\hline
\end{tabular}

${ }^{1} \mathrm{co}$ (control), diu (diuron - $2000 \mathrm{~g}$ a.i. ha ${ }^{-1}$ ), sul (sulfentrazone - $700 \mathrm{~g}$ a.i. ha ${ }^{-1}$ ), ame (ametryn $-1500 \mathrm{~g}$ a.i. ha ${ }^{-1}$ ). Single application for even number treatments. ${ }^{2}$ Two applications for these treatments. C.V. (coefficient of variation). *Means followed by the same letter in the column do not differ from one another by Scott and Knott's (1974) test ( $p<$ 0.05).

\section{Discussion}

Diuron, in one or two applications, did not reduce any of the evaluated parameters on the two cultivars, that becomes it a potentially selective herbicide. Similarly, Maia et al. (2012) verified the selectivity of diuron in post-planting application in the cultivar 'Pérola'. As well as Cruz et al. (2015) did not verify reductions in plant height and dry mass of the aerial part for application in pre-planting of the cultivar 'Imperial'. On the other hand, Maciel et al. (2011) verified reductions in plant height and leaf dry mass of 'MD-II Gold' pineapple cultivar for the application of diuron in combination with ametryn or bromacil + ametryn.

During the present study, ametryn isolated or associated with diuron in one or two applications was potentially selective for 'Pérola' cultivar. However, for the cultivar 'Smooth Cayenne' it was not observed, and only the diuron was presented as more selective.

The application of ametryn in preplanting did not affect photosynthetic parameters of 'Imperial' cultivar (CRUZ et al. 2014). As well as Cruz et al. (2015) did not observe reductions in variables related to the growth and development of 'Imperial' pineapple plants for the application of ametryn in pre- planting. In the same study, sulfentrazone at 0 , 200, 400 and $800 \mathrm{~g}$ a.i. ha $^{-1}$ in pre-planting, reduced some parameters according to the rates' increase, such as height and dry mass of the aerial part.

In the present study the sulfentrazone was not potentially selective for the 'Smooth Cayenne' and 'Pérola' cultivars, in post-planting application. However, it should be noted that this herbicide is recommended for application in pineapple both in pre-planting or post-planting (directed spray) up to the dose of $700 \mathrm{~g}$ a.i. ha ${ }^{-1}$ (RODRIGUES; ALMEIDA, 2018) as well as observed by Sison (2000), in which sulfentrazone (480 g a.i. ha ${ }^{-1}$ ), isolated or in combinations with diuron and bromacil, was selective for application in pre-planting of pineapple.

The few herbicide options registered in Brazil for post-planting application in pineapples in total area. Thus, noteworthy are the results thus obtained in the present study, in which diuron was potentially selective for one or two applications in post-planting of the cultivars 'Smooth Cayenne' and 'Pérola'. Also, ametryn was potentially selective in one or two postplanting applications of the cultivar 'Pérola', isolated or in combination with diuron. 
Thus, the results indicate the potential use of diuron, for both cultivars, and ametryn for the cultivar 'Pérola' in weed control during postplanting. Model and Favreto (2010) highlight the agronomic and economic efficacy of diuron for controlling weeds in pineapple crop, however, other management practices should be adopted for more effective control, such as the use of herbicides in pre-planting (SUWANARAK et al., 2000), herbicides tank mixture (MURRAY; HOFFMAN, 2000) and consortium with other crops (MATOS et al., 2009).

\section{Conclusions}

The growth and initial development of 'Smooth Cayenne' pineapple seedlings were not negatively influenced by the post-planting application of diuron (2000 g a.i. ha ${ }^{-1}$ ). In the same way, 'Pérola' pineapple seedlings were not negatively influenced by the post-planting application of diuron (2000 g a.i. ha ${ }^{-1}$ ) and ametryn (1500 g a.i. ha ${ }^{-1}$ ), both isolated or associated.

\section{References}

BRASIL. Ministério da Agricultura, Pecuária e Abastecimento. Agrofit - sistema de agrotóxicos fitossanitários. 2018. Available at: http://agrofit.agricultura.gov.br/agrofit cons/pri ncipal agrofit cons. Consulted at: April, 2018.

CABRAL, J. R. S. Variedades de abacaxi. Cruz das Almas: Embrapa Mandioca e Fruticultura, 2003. (Circular Técnica 63).

CATUNDA, M. G.; FREITAS, S. P.; OLIVEIRA, J. G.; SILVA, C. M. M. Effects of herbicides on the photosynthetic activity of pineapple (Ananas comossus). Planta Daninha, v.23, n.1, p.115-121, $2005 . \quad$ http://dx.doi.org/10.1590/s010083582005000100014

CATUNDA, M. G.; FREITAS, S. P.; SILVA, C. M. M.; CARVALHO, A. J. R. C.; SOARES, L. M. S. Weed interference in nutrient accumulation and pineapple crop growth. Planta Daninha, v.24, n.1, p.199-204, 2006. http://dx.doi.org/10.1590/S0100$\underline{83582006000100025}$

CRUZ, L. I. B.; CRUZ, M. D. C. M.; CASTRO, G. D. M.; FAGUNDES, M. C. P.; SANTOS, J. B. Growth and nutrition of 'Imperial' pineapple nursery plants associated with the fungus Piriformospora indica and herbicide application. Semina: Ciências Agrárias, v.36, n.4, p.2407-2422, 2015. http://dx.doi.org/10.5433/1679-

0359.2015v36n4p2407

CRUZ, L.I.B.; CRUZ, M.D.C.M.; FERREIRA, E.A.; CASTRO, G.D.M.D.; ALMEIDA, M.D.O. Quantum efficiency of photosystem II of 'Imperial' pineapple nursery in response to association with the Pirifonnospora indica and herbicide. Revista Brasileira de Fruticultura, v.36, n.4, p.794-804, 2014. http://dx.doi.org/10.1590/0100-2945$\underline{411 / 13}$

MACIEL, C. D. G.; POLETINE, J. P.; LIMA, G. R. G.; OLIVEIRA NETO, A. M.; GUERRA, N.; JUSTINIANO, $W$. Seletividade de espécies bromeliáceas a herbicidas inibidores do fotossistema II. Global Science and Technology, v.4, n.1, p.82-89, 2011.

MAIA, L. C. B.; MAIA, V. M.; ASPIAZÚ, I.; PEGORARO, R. F. Growth, production and quality of pineapple in response to herbicide use. Revista Brasileira de Fruticultura, v.34, n.3, p.799-805, $2012 . \quad$ http://dx.doi.org/10.1590/s0100$\underline{29452012000300020}$

MATOS, A. P. Produção integrada de abacaxi. In: Produção integrada de fruteiras tropicais. Cruz das Almas: Embrapa Mandioca e Fruticultura, 2012. p.25-68.

MATOS, A. P.; SANCHES, N. F.; S. SOUZA, L. F.; ELIAS JÚNIOR, J.; TEIXEIRA, F. A.; SIEBENEICHLER, $S$. C. Cover crops on weed management in integrated pineapple production plantings. Acta Horticulturae, v.822, p.155-160, 2009. https://doi.org/10.17660/ActaHortic.2009.822.18

MELETTI, L. M. M.; SAMPAIO, A. C.; RUGGIERO, C. Progress in the brazilian tropical fruitculture. Revista Brasileira de Fruticultura, v.33, n. esp. 1, p.73-75, 2011. http://dx.doi.org/10.1590/s0100$\underline{29452011000500010}$

MODEL, N.; FAVRETO, R. Comparação de custos de tratamentos de controle de plantas daninhas em abacaxizeiro cultivado no Rio Grande do Sul, Brasil. Pesquisa Agropecuária Gaúcha, v.16, n.12, p.45-50, 2010.

MODEL, N.; FAVRETO, R.; RODRIGUES, A. E. C. Efeito de tratamentos de controle de plantas daninhas sobre produtividade, sanidade e 
qualidade de abacaxi. Pesquisa Agropecuária Gaúcha, v.16, n.1, 51-58, 2010.

MODEL, N.; FAVRetO, R.; RODRIGUES, A. E. C. Efeito do preparo de solo e de técnicas de plantio na composição botânica e biomassa de plantas daninhas no abacaxizeiro. Pesquisa Agropecuária Gaúcha, v.12, n.1-2, p.57-64, 2009.

MURRAY, D.A.; HOFFMAN, J. E. To ascertain the ideal combinations of atrazine and/or diuron with thiazopyr (Visor) in order that acceptable broad spectrum pre-emergent weed control in pineapples is achieved. Acta Horticulturae, v.529, III International Pineapple Symposium, p.289292, 2000. https://doi.org/10.17660/ActaHortic.2000.529.34

OLIVEIRA JÚNIOR, R.S. Mecanismos de Ação dos Herbicidas. In: OLIVEIRA JÚNIOR, R. S.; CONSTANTIN, J.; INOUE, M. H. Biologia e manejo de plantas daninhas. Curitiba: Ominipax, 2011. p. 141-142.

PIMENTEL-GOMES, F.; GARCIA, C. H. Estatística aplicada a experimentos agronômicos e florestais: exposição com exemplos e orientações para uso de aplicativos. Piraicicaba: Fealq, 2002.

RODRIGUES, B. N.; ALMEIDA. F. S. Guia de herbicidas. 7. ed. Londrina: Editing Authors, 2018.

SCOTT, A.J.; KNOTT, M. Cluster-analysis method for grouping means in analysis of variance. Biometrics, v.30, n.3, p.507-512, 1974. https://doi.org/10.2307/2529204

SISON, C. M. Sulfentrazone for preplant weed control in pineapple. Acta Horticulturae, v.529, p.303-307, 2000. https://doi.org/10.17660/ActaHortic.2000.529.36

SRIPAORAYA, S.; KEAWSOMPONG, S.; INSUPA, P.; POWER, J. B.; DAVEY, M. R.; SRINIVES, $P$. Genetically manipulated pineapple: transgene stability, gene expression and herbicide tolerance under field conditions. Plant Breeding, v.125, n.4, p.411-413, 2006. https://doi.org/10.1111/i.14390523.2006.01229.x

SUWANARAK, K.; KONGSAENGDAO, S.; VASUNUN $S$. Efficiency of pre-planting herbicides on weed control and growth of no tillage pineapple
(Ananas comosus L.). Acta Horticulturae, v.529, p.203-301, 2000. https://doi.org/10.17660/ActaHortic.2000.529.35

VELINI, E.D.; OSIPE, R.; GAZZIERO, D. L. P. Procedimentos para instalação, avaliação e análise de experimentos com herbicidas. Londrina: SBCPD, 1995. 